\title{
Benevolence-Oriented Filial Piety of Confucius
}

\author{
Xu Xiangqun \\ Foreign Language Academy of Shandong Women's University \\ Jinan, Shandong, China \\ xuxiangqun2007@163.com
}

\begin{abstract}
On the basis of his predecessors, Confucius made a connotative innovation of filial piety. Proposing that filial piety stemmed from the inner heart and was a manifestation of benevolence, he turned it from an external norm to an internal requirement of human heart. He transformed patriarchal filial piety of the Western Zhou Dynasty into filial piety as family ethics. He expanded filial piety from domain of family ethics to that of social ethics, and thus enriched the meaning of filial piety, making it more socially significant. He thought sacrificial filial piety was able to play an educational role.
\end{abstract}

\section{Keywords-Filial Piety ; Benevolence ; Confucius}

Confucius approved of the LiYue culture and system of the Western Zhou Dynasty, he remarked,"I prefer the present Chou civilization."[1] Confucius believed that the collapse of Rites of Zhou was the main reason for social unrest at that time, and therefore he proposed restoration of propriety to save society. Noticing that the external ritual system could no longer sustain, he turned to more intrinsic value "benevolence". His notion of benevolence was all-inclusive, and filial piety was considered as the foundation of benevolence. Therefore, Confucius proposed benevolence-oriented filial piety. His filial piety, on the one hand, was inherited from the tradition of venerating and sacrificing to one's ancestors, on the other hand, represented a further innovation based on the thought of filial piety from the Spring and Autumn Period.

\section{NATURAl Filial PIETy AS A MANIFESTATION OF}

\section{HUMAN NATURE}

Confucius claimed that filial piety was originated from the true feelings that children had for their parents. It was a manifestation of human nature. When asked about "three years mourning for parents", Confucius said, "It is only three years after his birth that a child is able to leave the arms of his parents. Now the period of three years mourning for parents is universally observed throughout the Empire. As to that man, - I wonder if he was one who did not enjoy the affection of his parents when he was a child! "[2] Here Confucius gave a reasonable explanation to "three years mourning for parents" from the perspective of reciprocating, claiming that it was nothing but an expression of true human feelings. Thus filial piety, pertaining to veneration of ancestors and binding of family order in the Western Zhou Dynasty, was transformed by Confucius into inner love stemmed from human nature and inherent requirement of humanity - benevolence.

There are two reasons for legitimate transformation of filial piety. The first is the denial of ancestral gods and other deities during the Spring and Autumn Period. The original "filial piety" has a strong religious connotation, which has so far largely lost its reasonable basis. The second is the declining of the patriarchal system, on which filial piety could no longer be based. Keen to see these, Confucius wisely turned people's attention to benevolence. By doing so, he found a more general and solid foundation for the existence of filial piety.

In proposing benevolence, Confucius built a foundation for the Chinese traditional concept of filial piety by echoing with human nature. In addition, filial piety was shifted from a relationship between different social levels in the Western Zhou Dynasty to benevolence of humanity infused with intrinsic equality. Thus, filial piety was transformed from a standard of aristocratic morality into a more universal morality for common people. In this way, the aristocratic color of filial piety in the Western Zhou Dynasty gradually faded, and the scope of applicability was broadened. Confucius said, "Is benevolence something remote or difficult? I wish to be benevolence, and then benevolence is here in hand. "[3] "If a man is virtueless, what does etiquette mean to him? If a man is virtueless, what does music mean to him? "[4] Benevolence was considered as a shared trait among all people.

Confucius stated that filial piety, which was the basis of benevolence, arose from true feelings of children for their parents. Benevolence was a kind of universally existing affection which was based on the kinship attachment among people. Confucius said, "When the gentlemen of a country earnestly favor their clansmen, benevolence will prevail among the people."[5] You Ruo, a disciple of Confucius also remarked, "Filial piety and fraternal love are the foundation of benevolence!"[6] Without filial piety and fraternal love, benevolence would be baseless. Since that, one should have both of them so as to be a man of benevolence. But they were only the beginning of but not the equivalent of benevolence. The notion of filial piety was expanded and upgraded to denote "loyalty" between the ruler and his ministers, "faithfulness" among friends, and finally "love for all", which was the highest state of "benevolence".

\section{Filial PIETY AS FAMILY Ethics FOR BOTH THE}

\section{MATERIAL AND THE SPIRITUAL}

Beyond the scope of benevolence, filial piety was also used as family ethics by Confucius. In this way, filial piety stressing spiritual reverence and material support for one's parents was sublimated to a new level. Various interpretations were put forward by Confucius under different situations. For example, when Meng Yizi asked what filial piety was, Confucius said, "Never go against the rules of propriety." [7] When Meng Wubo asked the same question, Confucius said, "Think how anxious your parents are when you are sick, and you will know your duty towards them."[8] When Zixia raised this question, Confucius gave another answer, "The difficulty is with the expression of your look." [9] Although Confucius did not offer a concentrated and systematic interpretation of filial 
piety, he involved almost all aspects of filial piety for the future generations.

Filial piety in the Western Zhou Dynasty period was merely material support, while Confucius's filial piety was a combination of spiritual veneration and material support-"no disobedience". He put forward that "The duty of an obedient son nowadays means only to be able to support his parents. But you also keep your dogs and horses alive. If there is no feeling of love and respect, where is the difference?" [10] In Confucius's opinion, material support was extrinsic behavior, and spiritual veneration was inner feelings. Veneration should be always kept in mind when a son showed filial piety to his parents. That was the unity of benevolence and propriety. How to respect one's parents? Firstly, a filial son should show his parents complaisant countenance. When $\mathrm{Zi}$ Xia asked what filial piety was, Confucius said, "The difficulty is with the expression of your look. That merely when anything is to be done the young people do it, and when there is food and wine the old folk are allowed to enjoy it, but can that alone be counted as real filial piety?" [11] If parents refused to take his advice, the filial son should also show respect and took the trouble to give advice again and again without complaining. Secondly, a son should be full of consideration for his parents. Confucius said, "Think how anxious your parents are when you are sick, and you will know your duty towards them."[12] "A son should always keep in mind the age of his parents, as a matter for thankfulness as well as for anxiety." [13] By combining spiritual veneration with material support, Confucius elevated the naturally existing parent-child relationship to the level of moral standard, which was a sublimation of filial piety.

Confucius proposed obedience to propriety and obedience to one's parents when mentioning "no disobedience". Confucius thought a filial son should serve his parents in an omnibearing way, "Never go against the rules of propriety", which means "when parents are still living, serve them according to the rules of propriety; when they pass away, bury them according to the rules of propriety, and offer sacrifices to them in line with the rules of propriety." [14] In Confucius's opinion, a filial son's true grief at his parent's funeral is the essence, for it is sincere and natural feelings towards his parents. Zeng Zi said, "I have heard the Master say, 'Men often do not themselves know what is really in them until they have to mourn the death of their parents.' " [15] During the whole period of three years mourning, an obedient son "Does not enjoy good food when he eats it, and derives no pleasure from music when he hears it; when he is lodged in comfort, he does not feel at ease: therefore, he does not do anything of those things." [16] People of different social hierarchy from the ruler to civilians should bury and offer sacrifices to their parents after they passed away according to the rules of propriety; and what's more, an obedient son should show feeling of love and respect in this period, "Possession of power without generosity; courtesy without seriousness, mourning without grief,- - I have no desire to look at such a state of things."[17] In Confucius's view, true grief for one's parent who passed away, but not the pomposity of funeral, was what mattered. The grief should come from love and respect for his parents and the emotion should be sincere and spontaneous.

Confucius firmly obeyed the rites of Zhou and insisted on carrying out three years of mourning. He remarked,
"We view a man by looking into his ideal while his father is still alive; when his father is dead, we watch his actions. If for three years after his father's death he does not change his father's principles, he may be counted as an obedient son."[18] He sang highly of Zi Zhang for his filial piety, "What other things he did on the occasion of the death of his father, other men can do. But what he did in keeping the old servants of his father and in following out the policy of his father, men will find it difficult to do." [19] From"being able to support" to "respecting without disobedience" and to "not changing one's parents' way of living for three years", Confucius developed filial piety as a combination of spiritual veneration and material support to a new height.

\section{FILIAL PIETY AS Social ETHICS BASED ON}

\section{LOYALTY}

Confucius's filial piety is mainly a concept of family ethics. Confucius combined filial piety, fraternal duty and loyalty together and expanded the social significance of filial piety. By doing so, filial piety became social ethics.

The concept of fraternal duty emerged in the Spring and Autumn Period, and it was associated closely with filial piety since Confucius. In The Analects, filial piety and fraternal love showed up in the same sentence for many times, "Young people should have filial piety when at home and show fraternal love when out, they should be cautious and truthful, have love for all, and develop closer relationship with virtuous people. Then when there is energy to spare, they may set out to learn classics."[20] "They are men who are considered by their relations and the local people to be dutiful to parents and respectful to brothers."[21] The connotation of fraternal duty was not limited to family and kinships, it was also a broad guideline for dealing with general social relations. The expansion and sublimation of filial piety and fraternal duty exerted a huge social impact. You Zi, one of Confucius's disciples correctly pointed out that "It's a rare case that a man who has filial piety and fraternal love will be liable to offend his superior, it never occurs that a man who doesn't offend his superior will rebel."[22] If everyone venerated the elderly, respected the superiors, and behaved oneself, the social disorders would not happen. A harmonious and stable environment could thus be created in society.

Confucius not only placed filial piety and fraternal duty side by side parallel, but also combined filial piety with loyalty. He extended filial piety towards one's parents to "loyalty" towards the ruler. In The Analects, "loyalty" has been mentioned for eighteen times, among which "loyalty to the ruler" is mentioned twice, and there is also a case of associating "loyalty" with "filial piety". Ji Kangzi who was a minister in power in Confucius' native state asked Confucius "What should be done to inspire a feeling of respect and loyalty in the people, in order to make them exert themselves for the good of the country?" Confucius answered, "Treat them with seriousness and they will respect you. Let them see that you honor your parents and your prince, and are considerate for the welfare of those under you, and the people will be loyal to you. Advance those who excel in anything and educate the ignorant, and the people will exert themselves."[23] Confucius believed that filial piety to one's parents was within the family context, and "loyalty to the ruler" was the extension of 
filial piety to political arena. Filial piety at home signified "loyalty to the ruler" outside of the family. This idea was the product of combining patriarchal filial piety during the Western Zhou Dynasty with the new social trend in the Spring and Autumn Period. Under patriarchal system in the Western Zhou Dynasty, the ruler-minister relations belonged to blood kinship relation. Filial piety connoted "loyalty" to the ruler. During the Spring and Autumn Period, the ritual system was in decline and patriarchal hierarchy was destroyed. It was then difficult to maintain patriarchal filial piety in the Western Zhou Dynasty, and connotation of filial piety was thus changed. "Loyalty" in the sense of loyalty to the ruler was already separated from filial piety at this time. In the Chronicle of Zuo which depicted social situation at that time, it was written that "Without loyalty and respect, with what can one serve the king?"[24] The change in the system of selecting officials during the Spring and Autumn period provided conditions for the separation of loyalty from filial piety. In the Western Zhou Dynasty, the official selection was based on clans and inheritance of social positions. While at this time, "gaining official positions by recommendation or other means was more commonly seen, which signified partial transferring of power center from patriarchal clan to ordinary bureaucrats".[25] To this point, no blood relationship existed between the ruler and his ministers, and therefore only loyalty could help maintaining the ruler-minister relations. Influenced by patriarchal filial piety in the Western Zhou Dynasty and for the purpose of adapting to the social situation, Confucius placed filial piety in the domain of family ethics. Therefore, when addressing filial piety in The Analects, Confucius sometimes talked about filial piety as family ethics, but at other times, as the residue of patriarchal filial piety. Linking "loyalty" with "filial piety", he considered the relationship between father and son was more important than that between the ruler and his ministers, that is to say, filial piety was placed on top of loyalty.

\section{Ritual Filial PIETy of PRACTICAL SignificANCE}

Filial piety inherited by Confucius was mainly characterized by worship and veneration of ancestors. It advocated sacrificial rituals for deceased parents and ancestors to fulfill one's filial piety. In Confucius's view, filial piety embodied in the rituals was originated from the inner feelings that one had towards his parents. These rituals were for comforting emotion, but could also play an educational role by meeting people's psychological needs. This is humanistic understanding of sacrificial ritual system

Confucius attached great importance to propriety of the funeral and strongly advocated "three years of mourning". This was not due to religious idea of spirit worship, but was based on moral obligation and affection towards people's kinships. It was a repayment for the love from parents as well as an expression of gratefulness, cherishing and remembrance for them. Parents gave lives to and took care of their children, therefore, the grown up children should honor and remember their parents even after they have passed away. How could filial piety for the deceased parents be manifested? The answer is through sacrificial rituals, which are "the continuation of spiritual veneration and material support towards the parents, and should be carried out on a regular basis and with respect."[26]
Confucius's worship of the spirits was aimed at obtaining psychological satisfaction, rather than seeking divine blessing.[27] Thus, ritual behavior was originated from emotions that needed to be comforted. It was not a path leading to divine existence of the objects; but it was important for successful realization of the order of human relations and self virtues. Mr. Feng Youlan once pointed out that "The Confucian interpretation of funerals and sacrificial rituals is not religious, but is completely poetic and artistic. It meets the emotional requirements of people in a poetic way."[28]

Confucius also argued that sacrificial rituals were not driven by external forces, but were completely originated from the hearts of human's.[29] Filial affection for ancestors was expressed through propriety, which played a role in maintaining the social order. Confucius said, "If sacrificial rites are abandoned, people who betray the dead and forget the living will be numerous." [30]

Moreover, filial affection expressed in sacrificial rituals could also serve the functions of maintaining family unity and educating people. On the one hand, a solemn ritual strengthened the sense of ancestral sameness for members of the same clan, which was conducive to family unity. On the other hand, the whole clan get together for rituals, which improved harmonious and coordinated relations in the clan. Confucius attached importance to sacrificial rituals, pointing out that filial piety during rituals could play an educational role. Because of this, hoping to set an example for people, later rulers in the Warring States Period advocated "repairing ancestral temples and venerating ancestors to educate people to fulfill their filial piety." [31]

In conclusion, on the basis of his predecessors, Confucius made a connotative innovation of filial piety. Firstly, proposing that filial piety stemmed from the inner heart and was a manifestation of benevolence, he turned it from an external norm to an internal requirement of the human heart. Secondly, he transformed patriarchal filial piety of the Western Zhou Dynasty into filial piety as family ethics. He also specified the detailed norms of filial piety as the combination of material support and spiritual respect. Thirdly, he proposed combination of filial piety and fraternal duty as well as combination of loyalty and filial piety. He expanded filial piety from domain of family ethics to that of social ethics, and thus enriched the meaning of filial piety, making it more socially significant. Finally, his sacrificial filial piety which transcended common thought of spirits was considered to be able to play an educational role. Echoing with filial piety originated from the inner heart, sacrificial filial piety also stemmed completely from human heart, and was not driven by external forces.

\section{REFERENCES}

[1] Chapter Ba Yi in The Analects

[2] Chapter Yang Huo in The Analects.

[3] Chapter Shu Er in The Analects.

[4] Chapter Ba Yi in The Analects.

[5] Chapter Tai Bo in The Analects

[6] Chapter Xue Er in The Analects.

[7] Chapter Wei Zheng in The Analects.

[8] Chapter Wei Zheng in The Analects.

[9] Chapter Wei Zheng in The Analects.

[10] Chapter Wei Zheng in The Analects. 
[11] Chapter Wei Zheng in The Analects.

[12] Chapter Wei Zheng in The Analects.

[13] Chapter Li Ren in The Analects.

[14] Chapter Wei Zheng in The Analects.

[15] Chapter Zi Zhang in The Analects.

[16] Chapter Yang Huo in The Analects.

[17] Chapter Ba Yi in The Analects.

[18] Chapter Xue Er in The Analects.

[19] Chapter Zi Zhang in The Analects.

[20] Chapter Xue Er in The Analects.

[21] Chapter $\mathrm{Zi} \mathrm{Lu}$ in The Analects.

[22] Chapter Xue Er in The Analects.

[23] Chapter Wei Zheng in The Analects.

[24] Chapter The 5th Year of Xi Gong in Chronicle of Zuo.

[25] $\mathrm{Xu}$ Zhuoyun.On Chinese ancient society-Social Changes in Spring and Autumn Period \& Warring Periods. Guang Dong Formal University Press.pp43, 2006.

[26] Chapter Ji Tong in The Rites.

[27] Chapter Tan Gong Xia in The Rites.

[28] Feng Youlan. History of Chinese philosophy. The first volumn. zhong Hua Shu Ju Press, pp424—429, 1961.

[29] Chapter Ji Tong in The Rites.

[30] Chapter Li Cha Xia in Da Dai Li Ji.

[31] Chapter Fang Ji in The Rites. 